\title{
Phytoprotection
}

\section{Transgenic crops : new weed problems for Canada?}

\section{S.I. Warwick, H.J. Beckie et E. Small}

Volume 80, numéro 2, 1999

URI : https://id.erudit.org/iderudit/706182ar

DOI : https://doi.org/10.7202/706182ar

Aller au sommaire du numéro

\section{Éditeur(s)}

Société de protection des plantes du Québec (SPPQ)l

\section{ISSN}

0031-9511 (imprimé)

1710-1603 (numérique)

Découvrir la revue

\section{Citer cet article}

Warwick, S., Beckie, H. \& Small, E. (1999). Transgenic crops : new weed problems for Canada? Phytoprotection, 80(2), 71-84.

https://doi.org/10.7202/706182ar

\section{Résumé de l'article}

Over 25000 transgenic field trials were conducted globally from 1986-1997, and many transgenic crops, including soybean (Glycine max), maize (Zea mays), tobacco (Nicotiana tabaccum), cotton (Gossypium hirsutum), canola (Brassica napus, B. rapa), tomato (Lycopersicon esculentum) and potato (Solarium tuberosum) have been commercially released. There has been a high adoption rate, with at least 28 million ha reported for 1998, with herbicide- and insect-resistant plants occupying 71 and $28 \%$ of the releases, respectively. The current status of commercial production of transgenic crops in Canada is summarized. Transgenic crops have the potential to change weed communities/populations in three principal ways, via: 1 ) escape and proliferation of the transgenic plants as 'weedy' volunteers with subsequent displacement of the crop, weed and/or natural vegetation; 2) hybridization with and transgene infiltration into related weedy and/or wild species, resulting in invigorated weeds and/or alteration of natural gene frequencies in these species; and 3) genetic changes in populations of unrelated species, as a result of changes to the environment, in particular herbicide-resistant (HR) transgenic crops and the development of HR weeds. Potential risk can be estimated a priori using knowledge of the systematics of crop/wild/weed complexes. Risk must be assessed on a case-by-case basis for each crop, each country/ecological region, and for each trait. Potential weed risks will be greater if crop volunteers are predisposed to becoming weedy, are well adapted to the Canadian climate and if sexually compatible wild species are present.
Ce document est protégé par la loi sur le droit d'auteur. L’utilisation des services d’Érudit (y compris la reproduction) est assujettie à sa politique d'utilisation que vous pouvez consulter en ligne.

https://apropos.erudit.org/fr/usagers/politique-dutilisation/ 


\title{
Transgenic crops : new weed problems for Canada?
}

\author{
Suzanne I. Warwick', Hugh J. Beckie ${ }^{2}$, and Ernest Small1 \\ 1. Eastern Cereal and Oilseed Research Centre, Agriculture and Agri-Food Canada, \\ Central Experimental Farm, Ottawa, Ontario, Canada K1A 0C6; email: \\ warwicks@em.agr.ca \\ 2. Saskatoon Research Centre, Agriculture and Agri-Food Canada, 107 Science Place, \\ Saskatoon, Saskatchewan, Canada S7N 0X2
}

\section{PHYTOPROTECTION $80: \mathbf{7 1 - 8 4}$}

\section{ABSTRACT}

Over 25000 transgenic field trials were conducted globally from 1986-1997, and many transgenic crops, including soybean (Glycine max), maize (Zea mays), tobacco (Nicotiana tabaccum), cotton (Gossypium hirsutum), canola (Brassica napus, B. rapa), tomato (Lycopersicon esculentum) and potato (Solanum tuberosum) have been commercially released. There has been a high adoption rate, with at least 28 million ha reported for 1998, with herbicide- and insect-resistant plants occupying 71 and $28 \%$ of the releases, respectively. The current status of commercial production of transgenic crops in Canada is summarized. Transgenic crops have the potential to change weed communities/populations in three principal ways, via: 1) escape and proliferation of the transgenic plants as 'weedy' volunteers with subsequent displacement of the crop, weed and/or natural vegetation; 2) hybridization with and transgene infiltration into related weedy and/ or wild species, resulting in invigorated weeds and/or alteration of natural gene frequencies in these species; and 3) genetic changes in populations of unrelated species, as a result of changes to the environment, in particular herbicideresistant (HR) transgenic crops and the development of HR weeds. Potential risk can be estimated a priori using knowledge of the systematics of crop/ wild/weed complexes. Risk must be assessed on a case-by-case basis for each crop, each country/ecological region, and for each trait. Potential weed risks will be greater if crop volunteers are predisposed to becoming weedy, are well adapted to the Canadian climate and if sexually compatible wild species are present.

\section{INTRODUCTION}

Transgenic species have had DNA, manipulated in the laboratory by recombinant methods, inserted into their genome. The transferred DNA or genes may include regulatory sequences required to modulate gene expression and may have been taken from microbes, plants or animals, or synthesized. Modern genetic engineering therefore allows novelties to be created that were not achievable through conventional plant breeding. Most commercial species that have been genetically transformed are crops. Genes that have been

Note du rédacteur: le texte ci-dessus est présenté tel que soumis / Editor's note : the above text is presented as submitted. 
transferred to crops ("transgenes") are advantageous. They may improve quality and productivity of crops, as well as increase resistance to diseases, pests, herbicides, and environmental stresses.

Concerns have been and continue to be raised as to the environmental and evolutionary consequences of large scale cultivation of transgenic crops (Abbott 1994; Dale 1994; Keighery 1995; Parker and Kareiva 1996; Raybould and Gray 1993, 1994; Rissler and Mellon 1996; Rogers and Parkes 1995; Snow and Palma 1997). In principle, new transgenic plants pose the same environmental risks as new plants generated by traditional breeding. In practice, it may prove that the risks from some transgenic novelties exceed considerably the risks posed by new conventionally-bred cultivars. Traditional plant breeding has been gradually changing adaptations in crops for many years, but transgenes may, in at least some cases, be able to produce larger and quicker jumps in adaptation. In this paper we will review the extent of transgenic crop field trials and releases in Canada and discuss the risk potential for changes in weed communities/populations as a result of transgenic crops.

\section{TRANSGENIC CROPS}

Over 25000 transgenic field trials were conducted globally from 1986-1997 (James 1997), and many transgenic crops (including soybean, maize, cotton, canola, potato, tomato, tobacco) have been commercially released in the United States, Argentina, Canada, Australia, Mexico, China, Spain, France and South Africa (James 1998). There has been a high adoption rate $(2.8,13$ and 28 million ha in 1996, 1997 and 1998, respectively) with herbicide- and insectresistant plants occupying 71 and $28 \%$, respectively, in 1998 (James 1997, 1998). Although relatively few species have been genetically modified to date, in the future a range of additional plants (such as minor crops and trees) will likely be available. In Canada, commercial production of transgenic crops is summarized in Table 1 . It should be noted that not all crops with herbicide resistance are transgenic, the "novel" trait instead introduced through traditional plant breeding. Both categories of plants, i.e, transgenic and those with novel traits, are subject to the same regulations in Canada.

\section{RISK ASSESSMENT BEGINS WITH BIOSYSTEMATIC DATA}

Traditional biosystematic data (classical taxonomy, hybridization, cytology, phytogeography, and ecology) provide the initial information base for all risk assessment. The first requirements are competent classification and correct naming of both crop and weed species, which facilitate retrieval of relevant in-

Table 1. Commercial production of crops ('000 ha) with «novel traits" in Canada

\begin{tabular}{llllll}
\hline Crop $^{\text {a }}$ & Trait & 1996 & 1997 & $1998^{\mathrm{b}}$ & 1999 \\
\hline Canola & Herbicide R & 142 & 1619 & $2960(55 \%)$ & $3900(75 \%)$ \\
& High laurate & & & $2.0(<1 \%)$ & $3.3(<1 \%)$ \\
Maize & Bt R & 8.5 & 122 & $283(28 \%)$ & $390(35 \%)$ \\
Soybean & Herbicide R & & 3.3 & $40(4 \%)$ & \\
Potato & Insect R & 0.4 & 2.9 & $4.1(3 \%)$ & \\
Flax & Herbicide R & 0.2 & 2.4 & $1.4(<1 \%)$ & \\
\hline
\end{tabular}

a Canola, Brassica napus and B. rapa; maize, Zea mays; soybean, Glycine max; potato, Solanum tuberosum; flax, Linum usitatissimum.

b 1998 total area per crop $=5.4,1.0,0.9,0.15$ and 0.9 million ha, respectively. 
formation. Next, potential candidates for intergenomic hybridization must be identified and assessed. Data on genetic relatedness can be used to predict which wild relatives are likely to hybridize with the crop (Warwick 1997). Systematic studies reveal the breeding system and sexual compatibility of related species, likelihood of crosses and the factors affecting the successful production and survival of hybrid progeny. Biogeographical information is needed, including the distribution of crop and wild relatives globally, their ecological requirements, status in natural environments and, if weedy, the areas of infestation and patterns of spread.

\section{TRANSGENIC TRAITS AND PREDICTING THE BEHAVIOUR OF TRANSGENES IN THE ENVIRONMENT}

Risk, i.e., the likelihood of escape of a transgenic trait and the environmental impact if such an escape occurred, must be assessed on a case-by-case basis for each crop, each country/ecological region, and for each trait. Attributes of genetically modified plants likely to increase evolutionary risk are given in Table 2. In assessing these, one must ask the question: do certain traits make plants weedy? Baker (1965) characterized "the ideal weed or super-generalist" by a number of specific traits which are summarized in Table 2(a). For decades, Baker's list of characters has been used as a quantitative index of weediness : the more traits on the list that a plant possesses, the worse its weedy potential and conversely, the fewer the traits, the less likely the plant will become a weed. This view was supported by Keeler's (1989) study which compared the distribution for 13 of Baker's "weedy" traits in 48 of the world's worst weeds, 20 non-weeds, and 20 crop species. She found that the worst weeds had $>80 \%$ (11 of 13 ) of the traits, nonweeds $59 \%$ and the crop plants only $42 \%$ of the traits. Baker's weediness guidelines were, in fact, adopted by the United States National Academy of Science and American industry in their safety arguments to regulatory bodies. Use of Baker's list to predict weediness has been strongly criticized by Williamson (1993), who found that an intermediate number of Baker's characters (4-5) were associated with maximum weediness and the most successful weeds in a study of 49 British annual crops. Our view is that while presence of Baker's characteristics may not be highly predictive of whether a species is predisposed to becoming a weed,

Table 2. Attributes increasing the evolutionary risk potential of genetically modified plants

a. Weediness or invasive attributes (e.g., vegetative propagation, self-compatibility, seed dormancy, propagules that are adapted to long-distance dispersal and easily distributed, ability to produce many propagules, ability to germinate in a wide range of conditions, early flowering, strong competitive ability, rapid growth, plasticity of growth, adaptation to disturbed habitats)

b. Pest/disease resistance

c. Environmental stress resistance (cold, drought, salt tolerance)

d. Seasonal adaptation (perennial to annual, daylength response)

e. Toxic, allelopathic or anti-feedant chemicals, or of chemicals with hormone-like effects

f. Adaptation to new symbiotic microorganisms (such as nitrogen-fixing bacteria, mycorrhizal fungi) that increase survivability

g. Sexual compatibility with weedy and/or wild species 
absence of most or all of these traits suggests that the plant is less likely to become weedy.

The study of invasions suggests that the probability of detecting potential pest problems or other undesirable outcomes at an early stage is not large. Williamson (1993) described the "tens rule" to predict the likelihood of a new introduction becoming a weed. $\mathrm{He}$ estimated that $10 \%$ of imported species would become feral (i.e., become casual escapes or adventive), $10 \%$ of ferals become established, and $10 \%$ of those become pests. Transgenic crops have and will likely continue to become widely adopted, and therefore may be difficult to control whether a problem arises slowly or not. The most likely habitats to be affected by transgenes are disturbed habitats, agricultural areas, roadsides and waste areas, including grasslands (particularly when they are over grazed), riparian habitats, and waterways.

\section{POTENTIAL WEED COMMUNITY/POPULATION CHANGES DUE TO TRANSGENIC CROPS}

Transgenic crops have the potential to change weed communities/populations in three principal ways, via the: 1) escape and proliferation of the transgenic plants as 'weedy' volunteers in either agricultural/disturbed habitats or in natural habitats with subsequent displacement of crop, weed, or natural vegetation; 2) hybridization with and transgene infiltration (i.e., introgression) into related weed and non-weed species, resulting in invigorated weeds (often referred to as "super-weeds") and/or alteration of natural gene frequencies in these species; and 3) genetic changes in populations of unrelated species. For example, crops engineered to be herbicide or pest resistant may encourage greater use of particular herbicides and increase selection pressure for resistant biotypes in unrelated weeds or pests. These risks are illustrated in Figure 1.

\section{Weed risk \# 1}

The first principal risk is the possibility that genetic transformation of a plant, which has not shown significant weediness, will transform it into a weed capable of occupying agricultural and nearby disturbed sites and/or displacing native vegetation. All new plant lines selected by humans have had their adaptive potential modified, and the weedy potential of most economic species, including those that have been genetically transformed or may be in the future, is known to an appreciable
Unrelated species

Crop becomes a weed

seed

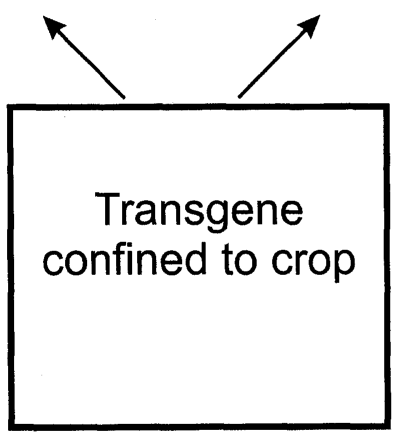

genetically altered weediness increased
Non-weed species genetically altered weediness increased invigorated

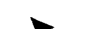

\section{.}

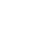


degree. Generally, highly domesticated plants have been deprived of some of their natural resistance to environmental conditions and so tend not to be competitive in the wild (e.g., maize) and so are not capable of directly entering natural ecosystems. Transformed plants that a) have been too weakened by domestication to survive without humans or b) represent species that are quite unadapted to the climates of a country, are very unlikely to have acquired the capacity to survive outside of cultivation. Some crops, however, are not significantly debilitated by domestication, and are either already weeds in certain situations, e.g. bird rape (B. rapa L.) and sunflower (Helianthus annuus $\mathrm{L}$.), or close to being weeds, e.g. alfalfa (Medicago sativa L.) and other forages (Raybould and Gray 1993; Rissler and Mellon 1996). These crops already possess traits needed to confer weediness or are likely not separated from weediness by a large numbers of traits. A single gene difference, or at most a closely linked gene complex, in cultivated oats (Avena sativa L.) is responsible for "fatuoid" characters in wild oats ( $A$. fatua L.). Other examples where few genetic changes have enhanced a plant's invasiveness are reviewed in Rissler and Mellon (1996). The suggestion that the transfer of one or just a few genes to crops is unlikely to create weeds is clearly not applicable to all crops.

Certain categories of transformed plants pose significant risks, particularly those that are hardy, perennial, competitive, open pollinating and prolific, have a wide range of relatives with which they hybridize and an ability to colonize a range of natural and seminatural habitats (Small and Warwick 1999; Sweet et al. 1999). Examples of such plants are grasses, range and pasture species, aquatic plants and certain indigenous and introduced trees and shrubs.

Tolerance to local stresses determines whether or not any plant, including those that have been genetically transformed, can survive. Transgenes associated with increased stress resistance may be able to extend the environmental range in which a given crop can be cultivated. Stress resistance characteristics that increase survival under domestication have the potential of also increasing survival in the wild, and therefore of turning cultivated plants into weeds. Accordingly, genetically transformed plants with stress-tolerant transgenes need to be given special scrutiny (Small and Warwick 1999; Sweet et al. 1999).

\section{Weed risk \# 2}

The second principal risk is the possibility of hybridization with and transgene infiltration into related weed and/ or wild species, resulting in invigorated weeds ("super weeds") occupying agricultural/disturbed sites and/or alteration of natural gene frequencies in these species. Weeds that are presently inconsequential could be invigorated to the point that they become serious. Weeds that are already very successful could become even more of a problem than at present. Many crops have weedy forms of the species, or related weedy species, which have the potential of becoming invigorated as a result of introgression; indeed, about $20 \%$ of cultivated crops have established, closely related, weedy relatives (Keighery 1995), and these are often present near or in cultivated fields. Well documented cases of gene flow between select crops and related weedy species are given in Table 3. Cases of increased aggressiveness in weeds because of gene flow from related crops are known. Risk of weed invigoration is increased in proportion to the degree of sexual compatibility between the crop and its weedy relatives, because this increases the likelihood of transfer of the transgenes.

As discussed previously, the tens rule estimates that on average about $1 \%$ of newly introduced non-transgenic plants will become significant weed problems (Williamson 1993); whether or not new transgenic weeds would be equally problematical is an open question. The status (distribution, abundance, escape, etc.) of weeds currently in a country provides a benchmark for predicting to 
PHYTOPROTECTION 80 (2) 1999

Table 3. Examples of gene movement between crop plants and related taxa (reviewed in Raybould and Gray 1994; Dale 1994; Warwick 1997)

$\begin{array}{ll}\text { Crop species } & \text { Related taxa }\end{array}$

Beta vulgaris L. subsp. vulgaris (sugar beet)

B. vulgaris subsp. maritima (L.) Arcangeli (wild beet)

Brassica napus L. (canola, rapeseed)

B. rapa $L$. (wild rape)

Chenopodium quinoa Willd. (quinoa)

C. berlandieri Moq.

C. texana (Scheele) Gray

Curcurbita pepo L. (squash or gourd)

D. carota L. subsp. carota (wild carrot)

Daucus carota L. subsp. sativus (Hoffm.) Arcangeli (carrot)

M. falcata $L$.

O. perennis Moench (perennial rice)

Oryza sativa L. (rice)

Pennisetum americanum subsp. americanum (pearl millet)

Raphanus sativus L. (radish)

$P$. americanum subsp. stenostachyum (Klotzsch) Brunken (L.) Lecke (shibra)

R. raphanistrum L. (wild radish)

Setaria italica (L.) Beauv. (foxtail millet)

S. viridis (L.) Beauv. (green foxtail)

Sorghum bicolor (L.) Moench (sorghum)

S. halepense (L.) Pers. (johnsongrass)

Zea mays L. (maize)

Z. mexicana (Schrad.) Kuntze (teosinte) 
what extent their success could be improved by acquiring transgenes for stress tolerance. It is clear that in northern countries cold tolerance limits the northwards penetration of all weeds, often to the point that there is very limited occurrence. In addition, most weedy plants tend to be adapted to disturbed habitats and their potential for harm is mainly in man-disturbed habitats as well as natural habitats, which are also intrinsically subject to change and disturbance.

The magnitude of the danger of genetic infiltration of transgenes is controversial, with experts having quite different viewpoints. Ellstrand (1992) suggested that the principal risk in releasing genetically modified crops is introgression into wild plants. Gregorius and Steiner (1993) suggested that gene transfer from transformed crops has already taken place, albeit not documented, and that such transfer is likely to increase as transformed crops become more popular. By contrast, Raybould and Gray (1994) were unable to identify any clear case of this. In support of the possible rarity of introgression into wild (as opposed to weedy) plants, Dale (1994) stated "There are, as far as I am aware, no documented cases of resistance genes, introduced by conventional breeding, becoming established in wild populations." In the UK, Raybould and Gray (1993) examined the probability of introgression from crops into wild species (both introduced weeds and indigenous species), and noted a range of probability from minimal to high, depending on the particular crop and its wild relatives. Similar analyses have been done for The Netherlands, Switzerland and Canada (reviewed in Small and Warwick 1999).

Even after the potential for gene transfer (i.e. the degree of sexual compatibility of the crop plant and weed species) has been documented, many additional factors will influence the rate of gene flow under field conditions. These include: the extent to which they may grow in the same location, distance from the parents, synchrony of flowering, abundance and method of pollen spread (insect or wind pollinated), distance of pollen movement and environmental conditions permitting cross pollination (Scheffler and Dale 1994). Evaluating the risks of hybridization can be a considerable challenge, and the literature provides only a partial guide to whether or not wild species can hybridize with crop species. Where there is a possible risk, crops can be grown at suitable distances from the wild relatives, or the crop can be grown in a way that pollen transport is minimized.

\section{Weed risk \# 3}

The third principal risk is genetic changes in populations of unrelated species, which are present in the habitat where transgenic plants are released. Unlike the second principal risk described above, where potential genetic change is due to gene flow between related species, changes in gene frequencies may also occur in unrelated species due to alteration of the environment. Pest, disease and HR crops will require different pesticide and herbicide inputs in order to exploit these novel traits. These modified management systems will themselves have an impact on agricultural environments. In particular, HR transgenic crops may hasten the evolution of HR weeds.

HR crops represented $71 \%$ of the 28 million ha of commercial transgenic crop production in 1998 (James 1998). Table 4 shows the current status of HR crops in Canada. Given the large number of HR crops and large acreages, it is very likely that increased herbicide use may accelerate the selection of HR biotypes in both related and unrelated weed species. Potential selection of HR biotypes is highest when a single herbicide class is used repeatedly in consecutive years, particularly if the herbicide is highly efficaceous, persistent and affects only one target site. The number of HR weeds (Table 5) has expanded geometrically during the past two decades from the first documented occurrence of triazine resistance in 1968 to 216 HR weed biotypes from 45 countries in 1998 (Heap 1999). Currently ALS (acetolactate synthase) and acetylCoA carboxylase (ACCase) inhibitor HR weeds represent the biggest problem, with 53 ALS inhibitor-resistant weed 
Table 4. Herbicide-resistant crops in Canada [+: field trial; C: commercially released]

\begin{tabular}{|c|c|c|c|c|c|c|c|}
\hline Group $^{a}$ & Product & Common name & Canola & Maize & Soybean & Wheat & Flax \\
\hline 2 & Pursuit & imazethapyrc & $+\mathrm{C}$ & + & & + & \\
\hline 2 & Odyssey & imazethapyr/imazamox ${ }^{c}$ & $+\mathrm{C}$ & & & & \\
\hline 2 & & sulfonylurea & & & & & $+\mathrm{C}$ \\
\hline 10 & Liberty & glufosinate & $+\mathrm{C}$ & + & & & \\
\hline 9 & Roundup & glyphosate & $+\mathrm{C}$ & + & $+\mathrm{C}$ & + & \\
\hline 6 & & bromoxynil & + & & & & \\
\hline 1 & Poast & sethoxydim & & + & & & \\
\hline
\end{tabular}

a Herbicide group.

b Chemical names: bromoxynil, 3,5-dibromo-4-hydroxybenzonitrile; glufosinate, ammonium 2-amino-4-(hydroxymethylphosphinyl)butanoic acid; glyphosate, $N$-(phosphonomethyl)glycine; imazamox, 2-(4-isopropyl-4-methyl-5-oxo-2-imidazolin-2-yl)-5-(methoxyme-thyl)nicotinic acid; imazethapyr, 2-[4,5-dihydro-4-methyl-4-(1-methylethyl-5oxo-1 H-imidazol-2-yl]-5-ethyl-3-pyridinecarboxylic acid; sethoxydim, 2-[1-(ethoxyimino) butyl]-5-[2-(ethylthio)propyl]-3-hydroxy-2-cyclohexen-1-one.

c Non-transgenic.

Table 5. Summary from 1998 international survey of herbicide-resistant weeds (Heap 1999)

\begin{tabular}{lll}
\hline Group $^{\text {a }}$ & Mode of action & No. weed biotypes \\
\hline 2 & ALS inhibitor & 53 \\
1 & ACCase inhibitor & 19 \\
22 & bipyridiliums (photosystem I) & 26 \\
4 & synthetic auxins & 17 \\
5 & photosynthesis (photosystem II) inhibitor & 60 \\
7 & photosynthesis (ureas) inhibitor & 14 \\
9 & EPSP synthase inhibitor & 2 \\
- & other modes of action & 25 \\
Total & & 216 \\
\hline
\end{tabular}

a Herbicide group.

b A biotype is defined as a weed species resistant to herbicide(s) from one group.

species reported in 14 countries and 19 ACCase inhibitor-resistant weed species reported in 17 countries. The initial high frequency of ALS inhibitor-resistant alleles in weed populations prior to herbicide use, the soil persistence of many ALS inhibitors and the large acreage treated repeatedly with ALS inhibitors worldwide have contributed to their rapid increase (Heap 1999). Nearly 30 HR weed biotypes have been reported in Canada (Table 6).

In 1998, 2.96 million ha of HR canola were planted in Canada (Barber 1999): $44 \%$ glyphosate-resistant, $29 \%$ imidazolinone-resistant, and $27 \%$ glufosinateresistant (Table 7). Will the sheer scale of introduction of resistant germplasm into the environment at one time increase weed problems with crop volunteers and/or increase the likelihood of transfer to weedy relatives? It has been suggested that HR crops are the transgenic plants from which introgression is most probable, since the intense selection pressure of herbicide use would maximize selection for hybrid progeny resulting from outcrossing events (Dyer et al. 1993). This risk is no doubt exacerbated by the fact that the mechanisms of resistance selected in weeds are often the same mechanisms chosen by genetic engineers to confer resistance to crops. Herbicide resistance, including resistance to herbicide groups $2,4,5$ and 22 , have been reported in several weedy members of the 
Table 6. Herbicide-resistant weeds in Canada

\begin{tabular}{|c|c|c|c|c|}
\hline Common name & Scientific name & Group $^{\mathrm{a}}$ & $\begin{array}{l}\text { First } \\
\text { report }\end{array}$ & $\begin{array}{l}\text { Current } \\
\text { distribution }\end{array}$ \\
\hline Wild carrot & Daucus carota $\mathrm{L}$. & 4 & 1957 & ON \\
\hline Lamb's-quarters & Chenopodium album $\mathrm{L}$. & 5 & 1973 & ON \\
\hline Common ragweed & Ambrosia artemisiifolia L. & 5 & 1977 & ON \\
\hline Green pigweed & Amaranthus powellii S. Wats. & $\begin{array}{l}5 \\
2\end{array}$ & $\begin{array}{l}1977 \\
1998\end{array}$ & $\begin{array}{l}\text { ON } \\
\text { ON }\end{array}$ \\
\hline $\begin{array}{l}\text { Late-flowering } \\
\text { goosefoot }\end{array}$ & $\begin{array}{l}\text { Chenopodium strictum Roth } \\
\text { var. glaucophyllum (Aellen) Wahl }\end{array}$ & 5 & 1978 & ON \\
\hline Bird rape & Brassica rapa L. & 5 & 1978 & QC \\
\hline Common groundsel & Senecio vulgaris $\mathrm{L}$. & 5 & 1978 & $\mathrm{BC}, \mathrm{ON}$ \\
\hline Redroot pigweed & Amaranthus retroflexus $\mathrm{L}$. & $\begin{array}{l}5 \\
2\end{array}$ & $\begin{array}{l}1979 \\
1998\end{array}$ & $\begin{array}{l}\text { ON } \\
\text { ON }\end{array}$ \\
\hline Yellow foxtail & Setaria glauca (L.) Beauv. & 5 & 1981 & ON \\
\hline Witch grass & Panicum capillare L. & 5 & 1981 & ON \\
\hline Barnyard grass & Echinochloa crusgalli (L.) Beauv. & 5 & 1981 & ON \\
\hline Wild mustard & Sinapis arvensis $\mathrm{L}$. & $\begin{array}{l}5 \\
4 \\
2\end{array}$ & $\begin{array}{l}1983 \\
1991 \\
1992\end{array}$ & $\begin{array}{l}\text { MB, ON } \\
M B \\
A B, M B\end{array}$ \\
\hline Kochia & Kochia scoparia (L.) Schrad. & 2 & 1988 & $A B, M B, S K$ \\
\hline Green foxtail & Setaria viridis (L.) Beauv. & $\begin{array}{l}3 \\
1\end{array}$ & $\begin{array}{l}1988 \\
1991\end{array}$ & $\begin{array}{l}A B, M B, S K \\
A B, M B, S K\end{array}$ \\
\hline Chickweed & Stellaria media (L.) Vill. & 2 & 1988 & $A B$ \\
\hline Wild oats & Avena fatua $\mathrm{L}$. & $\begin{array}{l}8 \\
1 \\
2 \\
25\end{array}$ & $\begin{array}{l}1989 \\
1990 \\
1994 \\
1994\end{array}$ & $\begin{array}{l}A B, M B, S K \\
A B, M B, S K \\
A B, M B, S K \\
M B, S K\end{array}$ \\
\hline Russian thistle & Salsola pestifer A. Nels. & 2 & 1989 & SK \\
\hline $\begin{array}{l}\text { Poor-man's } \\
\text { pepper-grass }\end{array}$ & Lepidium virginicum $L$. & 22 & 1993 & ON \\
\hline Canada fleabane & Erigeron canadensis $\mathrm{L}$. & 22 & 1993 & ON \\
\hline Hemp-nettle & Galeopsis tetrahit $\mathrm{L}$. & 2 & 1995 & MB \\
\hline False cleavers & Galium spurium L. & $\begin{array}{l}2 \\
4\end{array}$ & $\begin{array}{l}1996 \\
1996\end{array}$ & $\begin{array}{l}A B \\
A B\end{array}$ \\
\hline $\begin{array}{l}\text { Spiny annual } \\
\text { sow-thistle }\end{array}$ & Sonchus asper (L.) Hill & 2 & 1997 & $A B$ \\
\hline
\end{tabular}

a Herbicide groups : 1 = acetyl-CoA carboxylase (ACCase) inhibitors; 2 = acetolactate synthase (ALS) inhibitors; $3=$ dinitroanilines; $4=$ synthetic auxins; $5=$ photosystem II inhibitors; 8 = triallate/difenzoquat; 22 = bipyridiliums; 25 = flamprop-methyl. 
PHYTOPROTECTION 80 (2) 1999

Table 7. Herbicide-resistant canola (Brassica napus) ${ }^{\text {a: }}$ herbicide group, herbicide brand and common name, cultivars, numbers and distribution of resistant weeds in each herbicide group

\begin{tabular}{|c|c|c|c|c|}
\hline \multicolumn{3}{|c|}{ Herbicide } & \multirow[b]{2}{*}{ Cultivar } & \multirow[b]{2}{*}{ Resistant weeds } \\
\hline Group & Brand & Common name ${ }^{b}$ & & \\
\hline \multicolumn{5}{|c|}{ Currently available: } \\
\hline 2 & Pursuit & imazethapyr & Smart canola & 53 biotypes : 14 countries \\
\hline 2 & Odyssey & $\begin{array}{l}\text { imazethapyr } \\
\text { /imazamox }\end{array}$ & & \\
\hline 1,2 & Freedom Gold & $\begin{array}{l}\text { quizalofop-P-ethyl } \\
\text { (Group 1) } \\
+ \text { thifensulfuron methyl } \\
\text { (Group 2) }\end{array}$ & & $\begin{array}{l}\text { Group } 1: 19 \text { biotypes : } 17 \text { countries } \\
\text { Group } 2: 53 \text { biotypes : } 14 \text { countries }\end{array}$ \\
\hline 9 & Roundup & glyphosate & Roundup Ready & $\begin{array}{l}\text { Lolium rigidum : Australia (1996) } \\
\text { Lolium multiflorum :USA (1998) }\end{array}$ \\
\hline 10 & Liberty & $\begin{array}{l}\text { glufosinate } \\
\text { ammonium }\end{array}$ & Liberty Link & None to date \\
\hline \multicolumn{5}{|c|}{ Proposed ${ }^{\mathrm{c}}$ : } \\
\hline 6 & Compass $^{c}$ & bromoxynil & Navigator & None to date \\
\hline
\end{tabular}

a $B$. rapa resistant to glufosinate ammonium and glyphosate accounted for $8 \%$ of transgenic canola acreage.

b Chemical names are listed in Table 4, except thifensulfuron methyl, methyl 3-[[[[(4-methoxy-6-methyl-1,3,5-trazin-2yl)amino]carbonyl]amino]sulfonyl]-2-thiophenecarboxylate; and quizalofop-P-ethyl:(ethyl (R)-2-[4-[6-chloro-2-quinoxalinyl) oxy]phenoxy]propanoic acid.

c Proposed as herbicide for control of volunteer Smart canola. 
mustard family in Canada (Table 6) and Australia (Heap 1999). Hybridization studies (reviewed in Warwick 1997; Metz et al. 1997) have also indicated the possibility for genetic exchange between the Brassica crop species and related weedy species, including natural crossing of $B$. napus with $B$. rapa, $B$. juncea (L.) Czern., Hirschfeldia incana (L.) Lagr.-Foss. and Raphanus raphanistrum under field conditions in Europe. Recent field results in Australia on gene flow between $B$. napus and $R$. raphanistrum, suggest that rates of hybridization via gene flow are likely lower than selection for herbicide resistance through mutation (Rieger et al. 1999). This would indicate that weed species would be more likely to develop herbicide-resistant biotypes via selection for resistant alleles than from gene escape from crop/weed hybridization events. However, instead of only one mechanism of weeds developing herbicide resistance, namely mutations through selection pressure, there may be a slower but no less important mechanism, hybridization through gene flow.

Crop and herbicide rotations are management strategies designed to prevent or delay the development of resistant weed populations and selection of cross- and multiple-resistant biotypes. Implementation of these strategies requires particular care in the case of transgenic crops. For example, in a potential crop rotation of sulfonylurearesistant soybean and imidazolinoneresistant maize, weeds with cross resistance, i.e., resistance to the same herbicide group, ALS-inhibiting herbicides, will be selected for every year. Cross-resistance is documented in several weed species (Heap 1999). Multiple-resistance, i.e., resistance to two or more herbicide groups via different mechanisms, has been reported in only two species: Lolium rigidum Gaudin from Australia and Alopecurus myosuroides Huds. in Europe (Heap 1999). Instances of cross- and multiple-resistance may increase, if resistance transgenes escape into the seedbank forming volunteers in subsequent crops. Over a period of time, with the introduction of different transgenic HR lines, the possibility of unintentional gene stacking, i.e., the combining of two or more independent genes in a single plant, is likely. The first reported field occurrence of such multiple resistance in volunteer canola was in western Canada in 1998 (Downey 1999).

\section{FITNESS}

Fitness is the major factor affecting the establishment and spread of an "escaped" transgene. The selective advantage, i.e., positive fitness value, of the herbicide transgene is restricted to agricultural habitats where the herbicide is applied. If reduced fitness occurred as a result of the HR transgene, the transgene would not be expected to persist in non-agricultural habitats. On the other hand if the transgene does not affect plant fitness, it would obviously not be selected against, and could persist in populations in the absence of herbicide use. With the exception of triazine resistance, cross and multiple HR weed biotypes described thus far do not appear to suffer from reduced fitness (Warwick and Black 1993); transgenes conferring such a resistance will probably persist in the plant population even in the absence of selection pressure. Models for fitness-neutral, -reducing and -enhancing transgenes and effects of fitness changes on population size are described by van Raamsdonk and Schouten (1997) and Sweet et al. (1999).

The first extensive transgenic fitness studies were conducted in the UK by Crawley et al. (1993). They compared the invasiveness and ecological performance of two transgenic resistant lines of $B$. napus, one for the antibiotic kanamycin and a second for the herbicide glufosinate in 12 different environments, including exposure to various stresses (herbivory, pathogens, closed vegetation). HR rape displayed equal or less invasiveness than its non-transformed counterparts; this was not altogether surprising given the absence of herbicide selective pressure in the experimental design. Similar results were obtained by Fredshaven and Poulsen (1996) in Denmark and Belgium for 
transgenic glufosinate-resistant $B$. napus lines and transgenic glyphosateresistant sugar beet in competitive field trials in the absence of herbicide selection pressure. Transgenic glufosinateresistant and non-transgenic lines of $B$. napus had differing fitness, however, when compared in four different habitats in each of three climate regimes in the UK (Hails et al. 1997). Fitness costs associated with transgenic glufosinate resistance introgressed from $B$. napus into weedy $B$. rapa were negligible, suggesting that transgenic herbicide resistance is capable of introgressing into populations of $B$. rapa and persisting, even in the absence of selection due to herbicide application (Snow and Jorgensen 1999). Herbicide resistance is likely to confer less feral fitness advantage than disease or insect resistance (Kareiva et al. 1996). One of the first demonstrations of enhanced fitness was a Bt field study of transgenic insecticidal rapeseed (B. napus) under insect selection pressure (Stewart et al. 1997). Similar additive ecological advantage for a transgene was reported in a competitive field trial for viral- (beet necrotic yellow vein virus) resistant transgenic sugar beet in the presence of viral selective pressure (Bartsch et al. 1996).

\section{WEED MANAGEMENT CHALLENGES}

Crop and herbicide rotations are sound management strategies designed to prevent or delay the evolution of HR weeds. Inclusion of transgenic crops in the rotation may complicate herbicide rotation options, particularly when crops in a rotational series are resistant to the same herbicide group. To prevent overuse of particular herbicides and to effectively control volunteers of transgenic crops, good record keeping of transgenic crops grown and herbicides used, and proper seed handling and crop management practices are essential. Informative labeling is required for both crop and herbicide. Labeling herbicides with their site of action (i.e., herbicide group number) in Canada is pending (Beckie et al. 1999).

\section{RESEARCH NEEDS}

Further research is required in the following areas:

1. Seedbank longevity for transgenic crops. Research to understand environmental and management factors affecting seed dormancy of transgenic crops and practices that mitigate against crop volunteers are required.

2. Effect of large scale transgenic crop releases on frequency of gene flow between the crop and either weedy or wild relatives.

3. Effect of transgenes on plant fitness in weedy habitats. Field studies ideally should include treatments which simulate selection pressure and possible selective advantage conferred by the transgene, measure fitness under a range of competitive conditions and include fitness traits most likely to be affected by incorporation of the transgene.

4. Rate of accumulation of transgenes, i.e., gene stacking. Field monitoring of multiple resistance in HR crops resulting from intercrossing between two or more types of HR transgenic lines is needed to determine their frequency of occurrence and to ensure that current management practices can minimize and effectively control volunteers with multiple resistance.

\section{REFERENCES}

Abbott, R. 1994. Ecological risks of transgenic crops. Trends Ecol. Evol. $9: 280$ 282.

Baker, H.G. 1965. Characters and modes of origin of weeds. Pages 147-172 in H.G. Baker and G.L. Stebbins (eds.), The genetics of colonizing species. Academic Press, New York.

Barber, S. 1999. Transgenic plants : field testing and commercialisation including a consideration of novel herbicide resistant oilseed rape (Brassica napus L.). Pages 3-11 in Gene flow and agriculture : relevance for transgenic crops. British Crop Protection Council, Farnham, Surrey, UK. 
Bartsch, D., M. Schmidt, M. Pohl-Orf, C. Haag, and I. Schuphan. 1996. Competitiveness of transgenic sugar beet resistant to beet necrotic yellow vein virus and potential impact on wild beet population. Mol. Ecol. $5: 199-205$.

Beckie, H.J., F. Chang, and F.C. Stevenson. 1999. The impact of labeling herbicides with their site of action : a Canadian perspective. Weed Technol. (in press)

Crawley, M.J., R.S. Hails, M. Rees, D. Kohn, and J. Buxton. 1993. Ecology of transgenic oilseed rape in natural habitats. Nature $363: 620-623$.

Dale, P.J. 1994. The impact of hybrids between genetically modified crop plants and their related species : general considerations. Mol. Ecol. 3 : 31-36.

deWet, J.M.J., and J.R. Harlan. 1975. Weeds and domesticates : evolution in the manmade habitat. Econ. Bot. 29 : 99-107.

Downey, R.K. 1999. Gene flow and rape - the Canadian experience. Pages 109-116 in Gene flow and agriculture : relevance for transgenic crops. British Crop Protection Council, Farnham, Surrey, UK.

Dyer, W.E., F.D. Hess, J.S. Holt, and S.O. Duke. 1993. Potential benefits and risks of herbicide-resistant crops produced by biotechnology. Hortic. Rev. 15 : 367-408.

Ellstrand, N.C. 1992. Threat of gene escape via hybridization. Outlook Agric. 21 : 228.

Fredshaven, J.R., and G.S. Poulsen. 1996. Growth behaviour and competitive ability of transgenic crops. Field Crops Res. $54: 11-18$.

Gregorius, H.-R., and W. Steiner .1993. Gene transfer in plants as a potential agent of introgresssion. Pages 83-107 in K. Wöhrmann and J. Tomiuk (eds.), Transgenic organisms. Risk assessment of deliberate release. Birkhäuser Verlag, Basel, Switzerland.

Hails, R.S., M. Rees, D.D. Kohn, and M.J. Crawley. 1997. Burial and seed survival in Brassica napus subsp. oleifera and Sinapis arvensis including a comparison of transgenic and non-transgenic lines of the crop. Proc. Roy. Soc. London, Series B Biol. Sci. 264 : 1-7.

Heap, I.M. 1999. International survey of herbicide resistant weeds. Online. Internet 04 February 1999. Available [www. weedscience.com].

James, C. 1997. Global status of transgenic crops in 1997. ISAAA Briefs No. 5. International Service for the Acquisition of Agri-biotech Applications, Ithaca, NY. $31 \mathrm{pp}$.

James, C. 1998. Global review of commercialized transgenic crops: 1998. ISAAA Briefs No. 8. International Service for the Acquisition of Agri-biotech Applications, Ithaca, NY.
Kareiva, P., I.M. Parker, and M. Pascual. 1996. Can we use experiments and models in predicting the invasiveness of genetically engineered organisms? Ecology 77: $1670-1675$.

Keeler, K.H. 1989. Can genetically engineered crops become weeds? Biotechnology 7 : 1134-1139.

Keighery, G. 1995. The ecological consequences of genetic engineering. Search $26: 274-276$.

Metz, P.L.J., E. Jacobsen, and W.J. Stiekema. 1997. Aspects of the biosafety of transgenic oilseed rape (Brassica napus L.). Acta Bot. Neerl. 46 : 51-67.

Parker, I.M., and P. Kareiva. 1996. Assessing the risks of invasion for genetically engineered plants : acceptable evidence and reasonable doubt. Biol. Conserv. 78 : 193203.

Raybould, A.F., and A.J. Gray. 1993. Genetically modified crops and hybridization with wild relatives : a UK perspective. J. Appl. Ecol. 30 : 199-219.

Raybould, A.F., and A.J. Gray. 1994. Will hybrids of genetically modified crops invade natural communities? Trends Ecol. Evol. $9: 85-89$.

Rieger, M.A., C. Preston, T. Potter, and S.B. Powles. 1999. Gene flow from transgenic canola to wild radish - a model system to determine the risks. Pages 131-136 in Gene flow and agriculture : relevance for transgenic crops. British Crop Protection Council, Farnham, Surrey, UK.

Rissler, J., and M. Mellon. 1996. The ecological risks of engineered crops. The MIT Press, Cambridge, Massachusetts.

Rogers, H.J., and H.C. Parkes. 1995. Transgenic plants and the environment. J. Exp. Bot. 46 : 467-488.

Scheffler, J.A., and P.J. Dale. 1994. Opportunities for gene transfer from transgenic oilseed rape (Brassica napus) to related species. Transgenic Res. 3 : 263-278.

Small, E., and S.I. Warwick. 1999. Potential risk to Canadian biodiversity from transgenic plants accidentally released from imported commodities. Canadian Food Inspection Agency, Ottawa. (in press)

Snow, A.A., and P.M. Palma. 1997. Commercialization of transgenic plants : potential ecological risks. Bioscience $47: 86-96$.

Snow, A.A., and R.B. Jorgensen. 1999. Fitness costs associated with transgenic glufosinate tolerance introgressed from Brassica napus ssp. oleifera (oilseed rape) into weedy Brassica rapa. Pages 137-142 in Gene flow and agriculture : relevance for transgenic crops. British Crop Protection Council, Farnham, Surrey, UK. 
Stewart, C.N., Jr., J.N. All, P.L. Raymer, and S. Ramachandran. 1997. Increased fitness of transgenic insecticidal rapeseed under insect selection pressure. Mol. Ecol. 6 : 773-779.

Sweet, J.B., C.E. Norris, E. Simpson, and J.E. Thomas. 1999. Assessing the impact and consequences of the release and commercialization of genetically modified crops. Pages 241-246 in Gene flow and agriculture : relevance for transgenic crops. British Crop Protection Council, Farnham, Surrey, UK.

van Raamsdonk, L.W.D., and H.J. Schouten. 1997. Gene flow and establishment of transgenes in natural plant populations. Acta Bot. Neerl. 46 : 69-84.
Warwick, S.I. 1997. Use of biosystematic data, including molecular phylogenies for biosafety evaluation. Pages 53-65 in S. Matsui S. Miyazaki, and K. Kasamo (eds.), The 3rd JIRCAS Symposium : The 4th International symposium on the biosafety results of field tests of genetically modified plants and microorganisms. Japan International Research Center for Agricultural Sciences (JIRCAS), Symposium Series No. 5, Tsukuba, Japan.

Warwick, S.I., and L.D. Black. 1993. Relative fitness of herbicide-resistant and susceptible biotypes of weeds. Phytoprotection 75 (Suppl.) : 37-49.

Williamson, M. 1993. Invaders, weeds and the risk from genetically modified organisms. Experientia $49:$ 219-224. 